\title{
Cellulose Microfibrils as a Pore Former in Electroless Co-Deposited Anodes for Solid Oxide Fuel Cells
}

\author{
Rob Turnbull, Neil Shearer, Callum Wilson \\ Edinburgh Napier University, Edinburgh EH10 5DT, Scotland, UK
}

\begin{abstract}
A study was conducted to investigate the feasibility of Cellulose Microfibrils (CMF) as a pore former in the manufacture of Solid Oxide Fuel Cell (SOFC) anodes using Electroless Co-Deposition (ECD). Previous work into the use of ECD to produce SOFC anodes has found that the lack of porosity has restricted the maximum power density of the cell. Cellulose Microfibrils' unique combination of properties and morphologies should produce the required microstructure for SOFC's electrodes. Cellulose Microfibrils were evaluated as a pore former by their inclusion (using various bath loadings) in the production of ECD anodes. The anodes produced were then evaluated using a Scanning Electron Microscope, Mercury Porosimetry and Electrochemical Impedance Spectroscopy. The results showed that an anode produced with a $10 \mathrm{~g} / \mathrm{l}$ of a $1 \%$ solution of $\mathrm{CMF}$ as pore former, improved the open circuit voltage, maximum power density by reducing the overall resistance of the cell.
\end{abstract}

\section{Introduction}

Solid oxide fuel cells are electrochemical energy conversion devices which offer tremendous promise for delivering high electrical efficiency with significant environmental benefits (1). They produce an electrical current through an electrochemical reaction between hydrogen and oxygen at a porous electrode interface, by completing an electrical circuit with the emission of the harmless by-product of water (2). They are composed of a dense electrolyte layer that is sandwiched between two porous electrodes (anode and cathode) as shown in Figure 1.

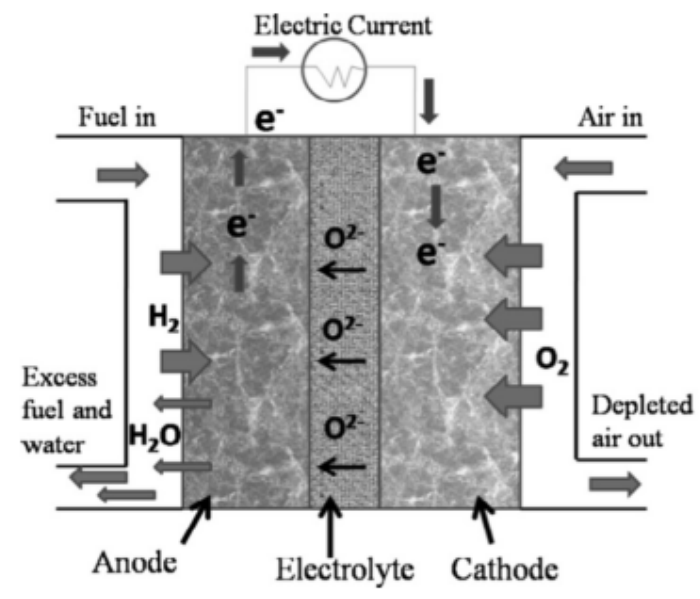

Figure 1. Layout of planar SOFC (1). 
One of the most important components of the SOFC is the anode, as it must catalyse the reaction of the fuel with the oxygen anions $\left(\mathrm{O}^{2-}\right)$ from the electrolyte and conduct the electrons produced in the electrochemical reaction to the external circuit (2). These electrochemical reactions occur at what is termed the Triple Phase Boundary (TPB) where the gas, ceramic and metal phases meet within the electrode (3).

The electrochemical performance of a fuel cell is limited by activation, ohmic and concentration polarisation during operation, which decreases the cell's overall power output. The slow reaction kinetics of the electrode gives rise to the activation polarisation, while the electrical resistance of the components induces the ohmic polarisation. Concentration polarisation arises due to the ineffective transportation of gases within the electrodes (4). The impact of this limitation within the anode will lead to a build-up of exhaust gases in the electrochemically active zone. This build up causes the oxidation of the nickel and dilutes the fuel concentration, reducing their performance significantly (5).

Therefore, the electrode is required to have a unique set of properties such as high electrical conductivity, matching thermal expansion coefficient with the other components, fine particle size with nanostructure, chemical compatibility with electrolyte, large triple phase boundary, high porosity and good electronic and ionic conductivity (2). Due to its low cost, good chemical stability and excellent catalytic activity nickel has been used as an anode material for many years. However, a pure nickel anode has a considerable mismatch of coefficient of thermal expansion (CTE) to the typical YSZ electrolyte. Therefore to counteract this mismatch in CTE, a cermet of nickel and YSZ is required (1) with an optimisation of the fine microstructure of the functional layer, which gives rise to the power density of the cells (4). This is typically achieved by producing an electrode with a good and precise fabrication method which produces a good metal to ceramic interaction as well as increasing the porosity (3).

Edinburgh Napier University has developed a new manufacturing process that enables the cost effective and efficient production of SOFC electrodes. Electroless CoDeposition (ECD), is a single plating operation which replaces the traditional techniques which involve a sintering and reduction stage. This simpler manufacturing process can be applied to any cell design and allows control over the ceramic and metal ratio and porosity (6).

Previous work on the process has shown that it is able to produce a working SOFC although the degree of porosity produced could be improved by the inclusion of pore formers, such as a sacrificial template (3). Since the shape of the void produced is closely related to the pore former used, a cylindrical pore former is more likely to produce the perpendicular channels required for maximum gas transportation efficiency (7). Cellulose is an abundant natural polymer which is renewable, biodegradable and non-toxic. It is insoluble in water and most organic solvents; it also has a hygroscopic nature and no melting point. The production of cellulose by photosynthesis is estimated to be $10^{11}-$ $10^{12}$ tons per year, with the major sources being wood and cotton (8).

Previous work by the author has shown that the inclusion of cellulose powders in the ECD process can increase the porosity of the coatings produced. Four powders, having 
various morphologies and sizes were used to investigate the feasibility of cellulose as a pore former in the ECD process. It was found that a smaller particulate powder $(20 \mu \mathrm{m}$ and $50 \mu \mathrm{m})$ had the greatest impact on the overall porosity of the coating, were as larger fibrous powders $(100 \mu \mathrm{m}$ and $200 \mu \mathrm{m})$ were unable to have a significant inclusion within the coating to truly evaluate their suitability. Therefore, a smaller fibrous cellulose would be required to investigate the morphology aspect of cellulose pore formers. Cellulose Microfibrils (CMF) which have a size of $10-50 \mu \mathrm{m}$ with an average of $30 \mu \mathrm{m}$, should be able to produce a more suitable microstructure than the powders previously used. This is due to their fibrous morphology and suitable size to act as a pore former within an ECD anode.

Therefore, to evaluate $\mathrm{CMF}$ as a pore former within the $\mathrm{ECD}$ process, a $1 \% \mathrm{CMF}$ solution was added to the ECD process to produce coatings on Alumina tiles using various bath loadings. These coatings were then evaluated by a Scanning Electron Microscope and Mercury Intrusion Porosimetry to determine the porosity and pore structure produced. Button cells were then produced using the same ECD method and bath loadings along with a standard Lanthanum Strontium Manganate (LSM) cathode on Yttrium Stabilised Zirconia (YSZ) electrolytes. These were then tested using EIS to determine the impact of the CMF pore former on the power capabilities of the cell.

\section{Experimental}

\section{$\underline{\text { Alumina Tile Production }}$}

Coatings were initially produced on $25 \mathrm{~mm}$ by $25 \mathrm{~mm}$ Alumina tile substrates to evaluate its feasibility as a pore former within the ECD process. These substrates were cleaned using an alkaline cleaner $\left(15 \mathrm{~min}, 60^{\circ} \mathrm{C}\right)$ and sensitized using solutions of tin chloride $\left(15 \mathrm{~min}\right.$, room temperature) and then palladium chloride $\left(15 \mathrm{~min}, 35^{\circ} \mathrm{C}\right)$. As the $\mathrm{CMF}$ in produced in a $1 \%$ solution, the constituent parts of a medium phosphorus $(6-9 \%$ P) nickel plating bath were added to CMF to produce the plating bath $\left(1\right.$ hour, $89^{\circ} \mathrm{C}, \mathrm{pH}$ 4.9). A bath loading of $10 \mathrm{~g} / \mathrm{l}, 5 / 1$ and $2 \mathrm{~g} / \mathrm{l}$ of CMF pore former and $50 \mathrm{~g} / \mathrm{l}$ of $\mathrm{YSZ}$ was used to produce the co-deposition coatings.

Half the tiles produced were then placed into a furnace programed with a heating profile of $5^{\circ} \mathrm{C} / \mathrm{min}$ to $450^{\circ} \mathrm{C}$, held for 3 hours before returning to room temperature at $10^{\circ} \mathrm{C} / \mathrm{min}$. All samples were then cut into sections to examine the cross section of the coatings before and after the removal of the pore formers using the SEM. Mercury Porosimetry was then used to determine the properties of the coating before and after the removal of the pore former.

\section{$\underline{\text { Cell Production }}$}

YSZ electrolytes were first roughened using 120 grit wet and dry paper in preparation for the ECD process. Cathode powders were manufactured using LSM and YSZ to produce the powder composition as shown in Table I. 
TABLE I. Cathode Powder Composition.

\begin{tabular}{ccc}
\hline Component & ${\text { Cathode } \mathbf{1}^{\text {st }} \text { Layer }}$ & Cathode 2 $^{\text {nd }}$ Layer \\
\hline LSM $(\mathrm{g})$ & 12.5 & 25 \\
YSZ $(\mathrm{g})$ & 12.5 & \\
PVP $(\mathrm{g})$ & 0.5 & 0.5 \\
\hline
\end{tabular}

These powders where mixed with a vehicle of Terpineol (95g) and PVB (5g) to produce the two printing inks required for the cathodes. The ink compositions are shown in Table II.

TABLE II. Cathode Ink Composition.

\begin{tabular}{ccc}
\hline Component & ${\text { Cathode } 1^{\text {st }} \text { Layer }}^{\text {st }}$ & Cathode 2 $^{\text {nd }}$ Layer \\
\hline $1^{\text {nd }}$ Layer Powder $(\mathrm{g})$ & 7.25 & 7.25 \\
Vehicle $(\mathrm{g})$ & 3.1 & 3.1 \\
\hline
\end{tabular}

The cathode was then produced by screen printing three layers of the $1^{\text {st }}$ layer ink and three layers of the $2^{\text {nd }}$ Layer ink. These were then sintered in a furnace programed to ramp at $3{ }^{\circ} \mathrm{C} / \mathrm{min}$ to $1100^{\circ} \mathrm{C}$, held for 2 hours and then decrease at $3^{\circ} \mathrm{C} / \mathrm{min}$ to $40^{\circ} \mathrm{C}$. The cells anodes were then produced using the same method to produce the coatings on the alumina tile.

\section{Results}

Figure 2 shows the SEM cross sections of the CMF coating on the alumina tile.
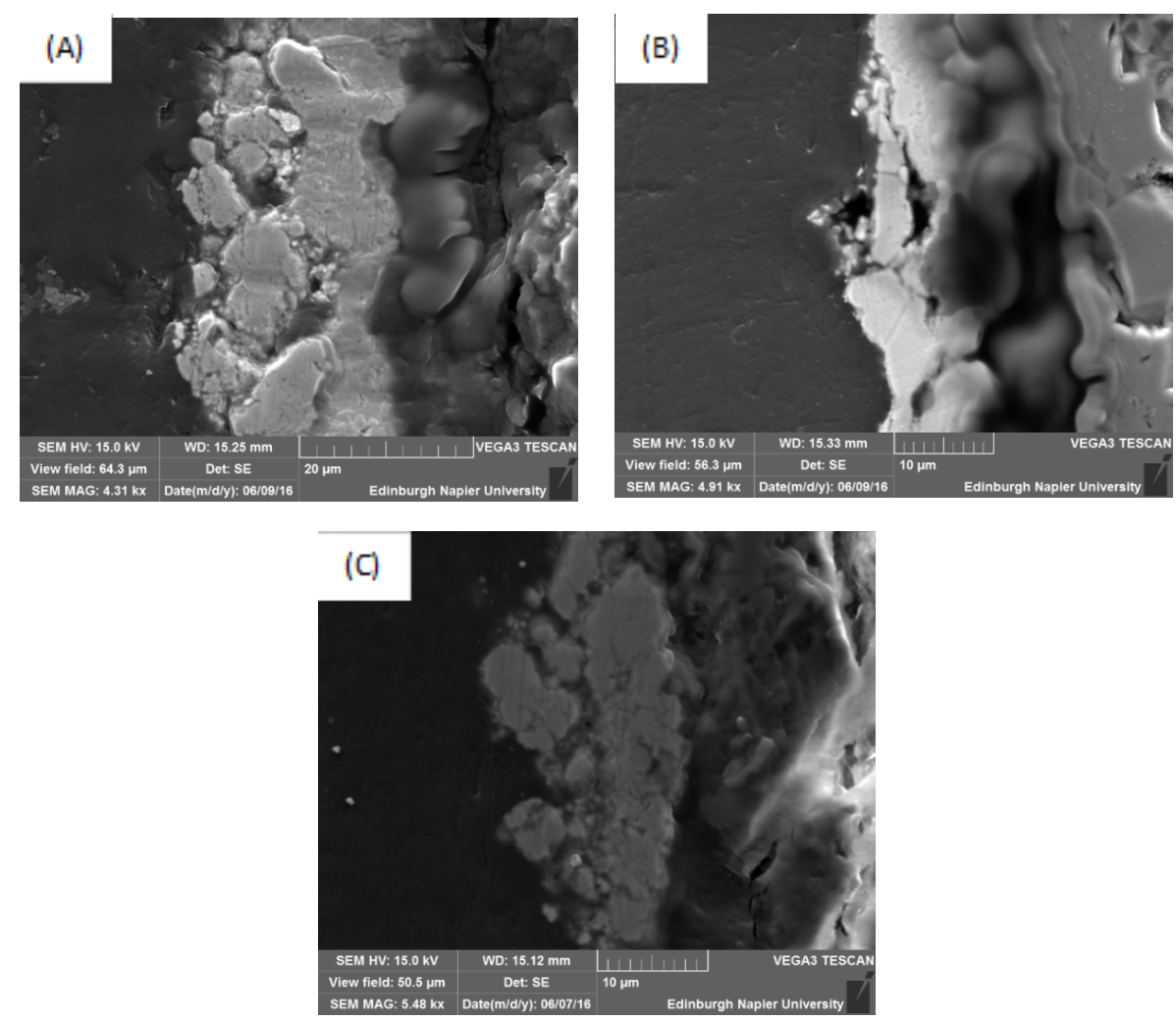

Figure 2: Cross Section of Samples A) 10g/l CMF B) 5g/l CMF C) 2g/l CMF. 
Figure 2 shows that the $\mathrm{CMF}$ is producing the necessary structures required for a functional SOFC anode. This is confirmed by the porosimetry results which are shown in Table 3.

Table III: Porosimeter Results.

\begin{tabular}{cccccc}
\hline Sample ID & Pore Former & $\begin{array}{c}\text { Total Pore } \\
\text { Volume } \\
\left(\mathbf{m m}^{\mathbf{3}} \mathbf{g}\right)\end{array}$ & $\begin{array}{c}\text { Total Pore } \\
\text { Surface Area } \\
\left(\mathbf{m m}^{\mathbf{2}} \mathbf{g}\right)\end{array}$ & $\begin{array}{c}\text { Average Pore } \\
\text { Diameter } \\
(\boldsymbol{\mu m})\end{array}$ & $\begin{array}{c}\text { Porosity by Hg } \\
\text { Intrusion } \mathbf{( \% )}\end{array}$ \\
\hline 1 & \multirow{2}{*}{$\mathrm{g} / \mathrm{l} \mathrm{CMF}$} & 0.64 & 0.024 & 0.1081 & 0.07 \\
2 & & 1.90 & 0.099 & 0.0768 & 0.21 \\
3 & $5 \mathrm{~g} / \mathrm{l} \mathrm{CMF}$ & 2.25 & 0.129 & 0.0701 & 0.25 \\
4 & & 1.11 & 0.017 & 0.2579 & 0.12 \\
5 & $2 \mathrm{~g} / \mathrm{l} \mathrm{CMF}$ & 0.54 & 0.007 & 0.2931 & 0.06 \\
6 & & 1.48 & 0.341 & 0.0173 & 0.14 \\
\hline
\end{tabular}

These results were used to calculate the percentage change, which are summarised in graphs in Figure 3.
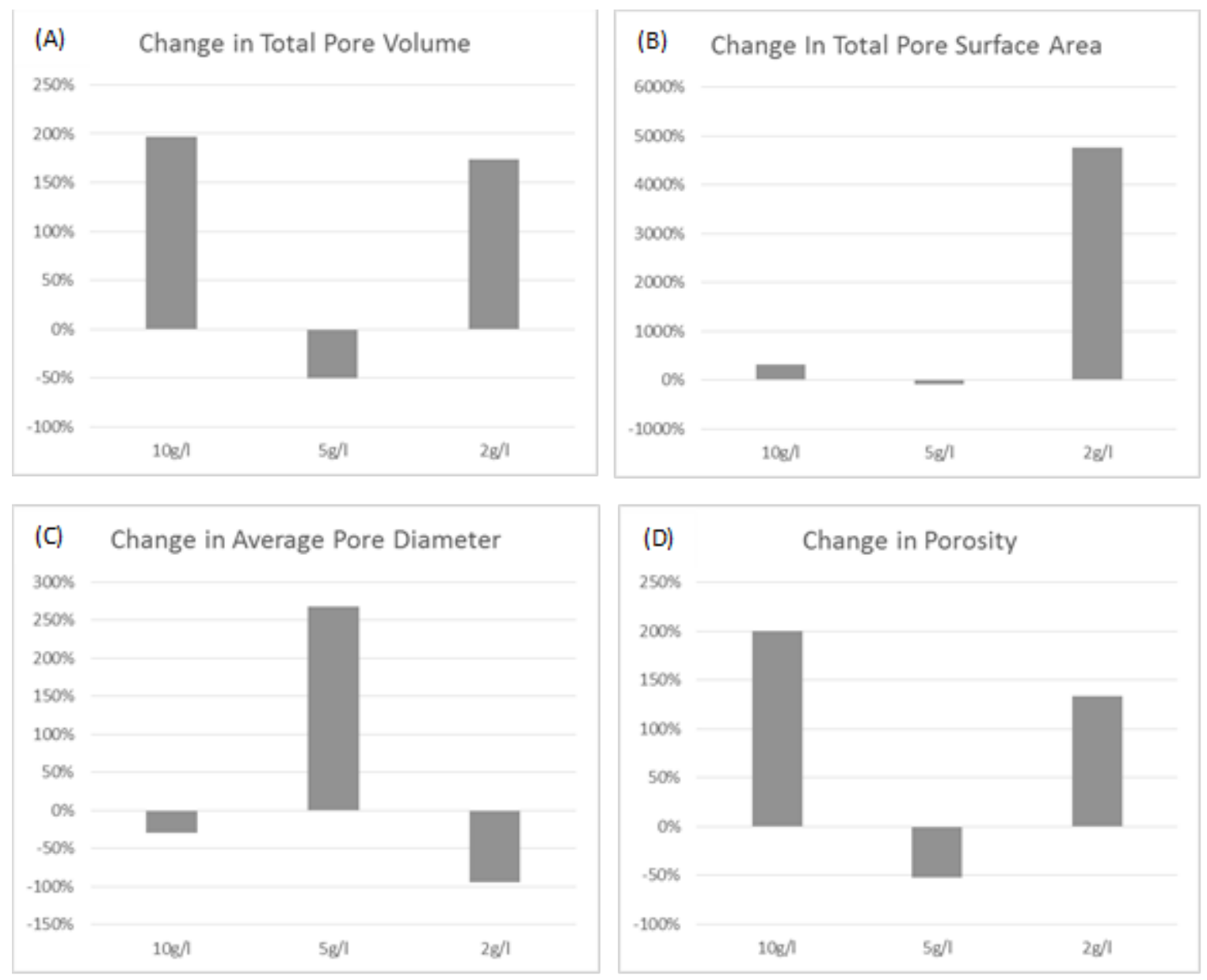

Figure 3. Summarised Porosimeter Results: (A) Change in Total Pore Volume, (B) Change in Total Pore Surface Area, (C) Change in Average Pore Diameter, (D) Change in Porosity. 
The results in Table 3 and Figure 3 show that the inclusion of the CMF is producing a more porous coating, except for the $5 \mathrm{~g} / 1$ which is reducing the porosity. The button cells that produced were then tested using EIS at $700^{\circ} \mathrm{C}, 750^{\circ} \mathrm{C}$ and $800^{\circ} \mathrm{C}$ to determine their power capabilities; the i- $\mathrm{V}$ characteristics are shown in Figure 4.
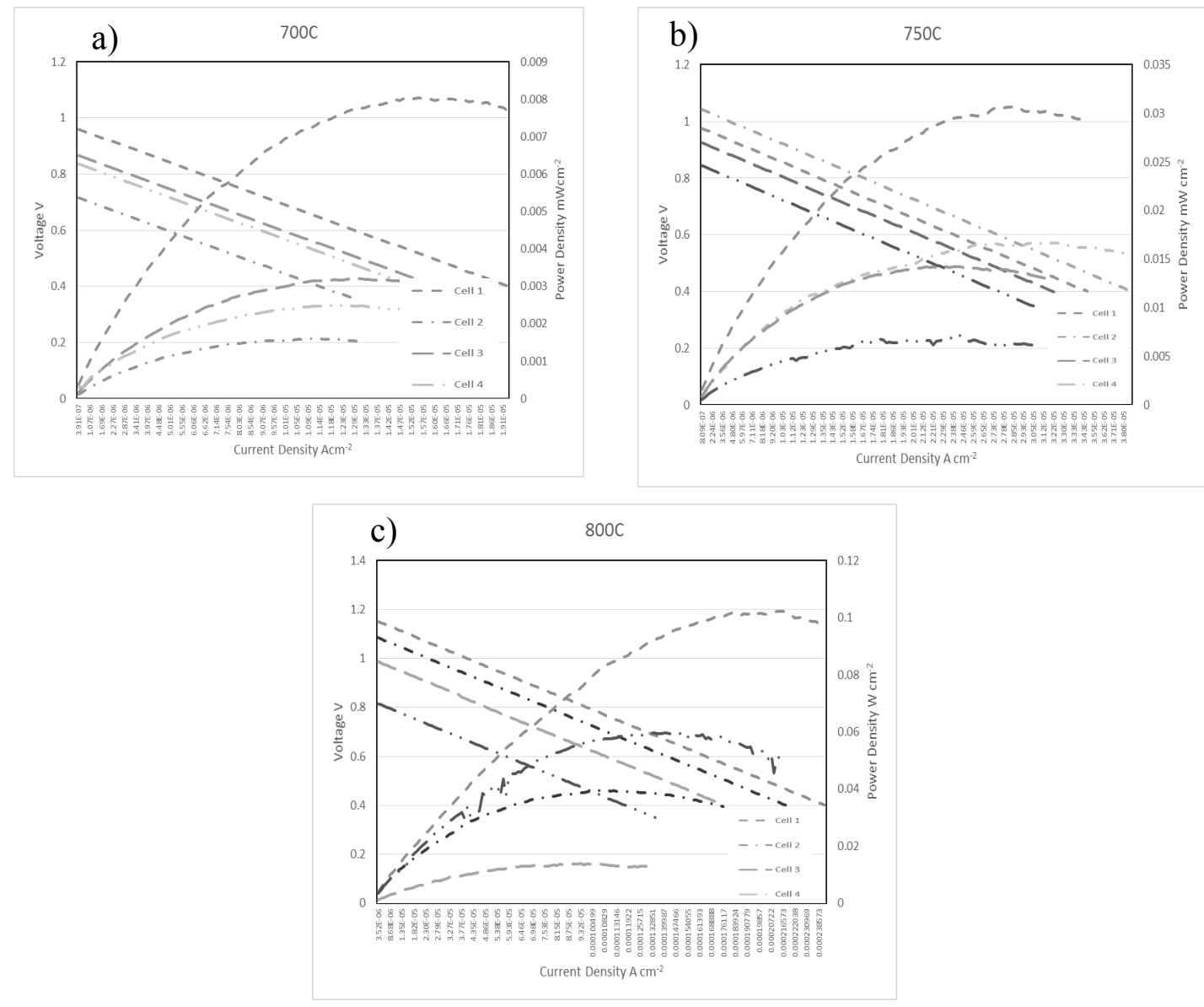

Figure 4. i-V characteristics for Cells $1-4$ at a) $700^{\circ} \mathrm{C}$, b) $750^{\circ} \mathrm{C}$ and c) $800^{\circ} \mathrm{C}$.

The open circuit voltage and maximum power density for each of the cells are shown in Table IV.

TABLE IV. OCV and Power Density of Cells.

\begin{tabular}{cccc}
\hline Cell ID & Temp $\left({ }^{\circ} \mathbf{C}\right)$ & OCV (Volts) & Power Density $\left(\mathbf{m W ~} \mathbf{~ c m}^{-2}\right)$ \\
\hline Cell 1 & 700 & 1.006 & 0.008 \\
& 750 & 1.079 & 0.031 \\
Cell 2 & 800 & 1.09 & 0.108 \\
& 700 & 0.725 & 0.002 \\
& 750 & 0.914 & 0.020 \\
Cell 3 & 800 & 0.991 & 0.058 \\
& 700 & 0.76 & 0.003 \\
& 750 & 0.794 & 0.013 \\
Cell 4 & 800 & 0.823 & 0.036 \\
& 700 & 0.604 & 0.003 \\
& 750 & 0.671 & 0.015 \\
& 800 & 0.691 & 0.027 \\
\hline
\end{tabular}


Table 4 shows that Cell 1 is producing the maximum power density of all the cells tested at $0.1 \mathrm{~mW} \mathrm{~cm}^{-2}$ at $800^{\circ} \mathrm{C}$, this was three times higher than Cell 4 which had no pore former, the impedance spectra at OCV is shown in Figure 5.
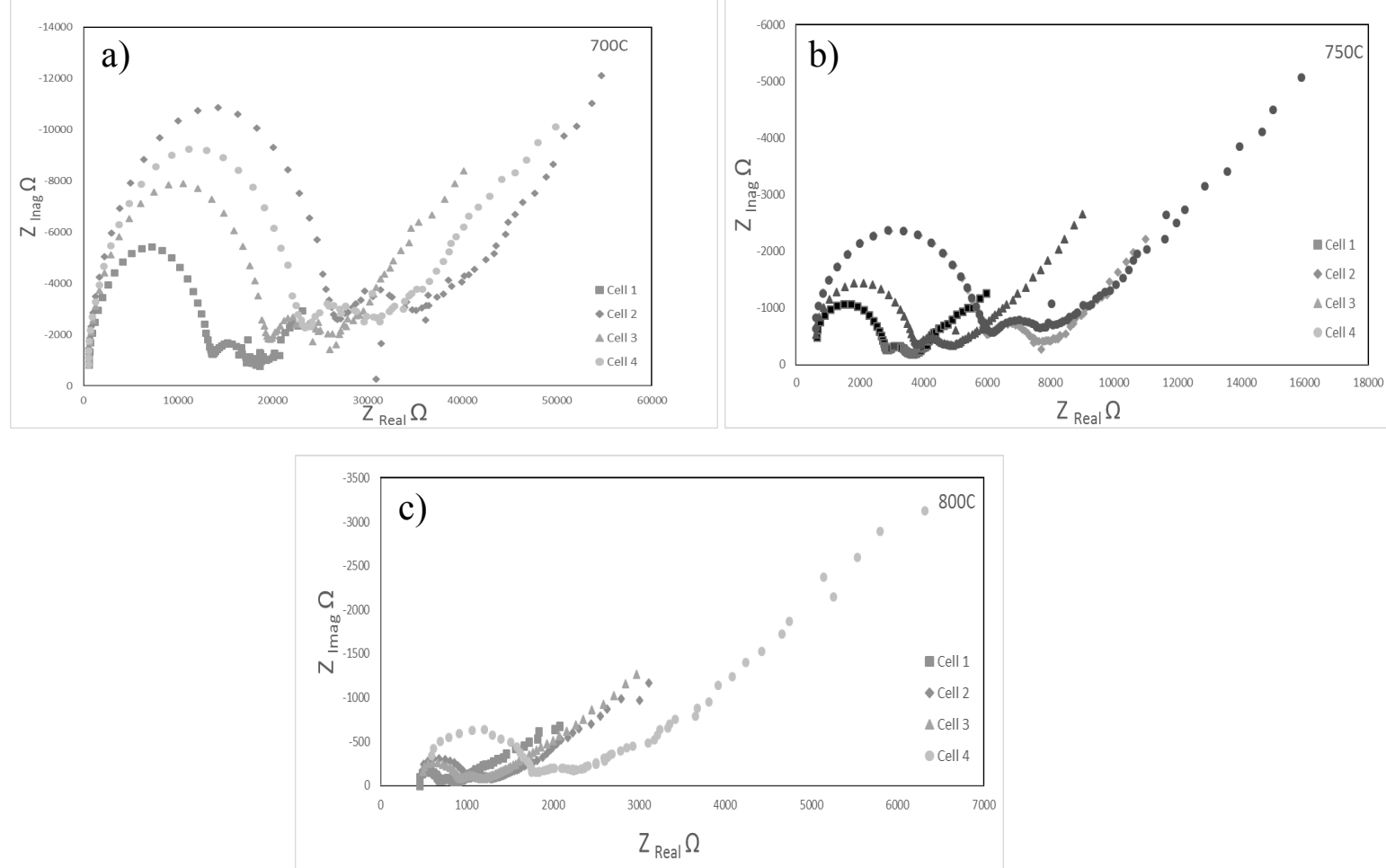

Figure 5. Impedance Spectra for Cells $1-4$ at a) $700^{\circ} \mathrm{C}$, b) $750^{\circ} \mathrm{C}$ and c) $800^{\circ} \mathrm{C}$.

To analyse the impedance spectra, an equivalent circuit was created, which is shown in Figure 6.

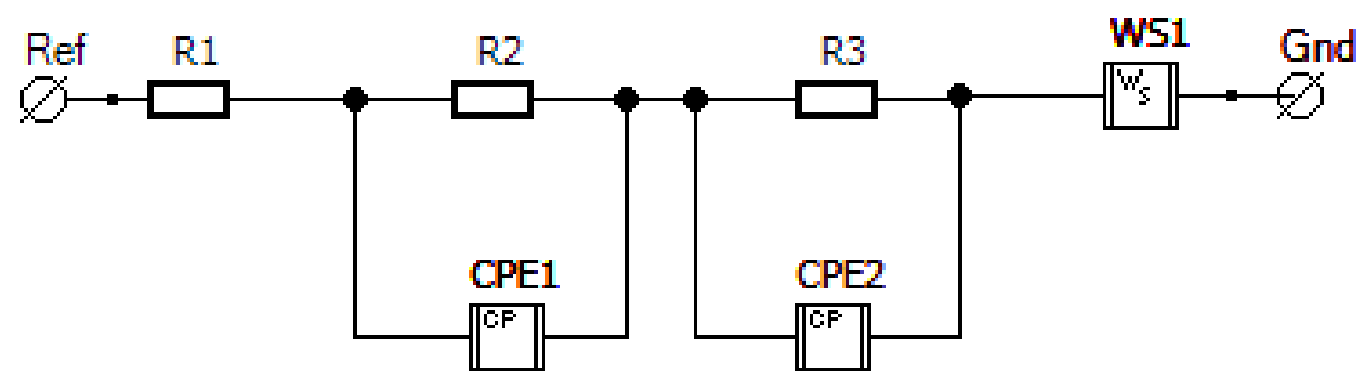

Figure 6. Equivalent Circuit model used to fit Impendence Spectra.

The equivalent circuit consists of three resistors, two constant phase elements and a Warburg short circuit element, the fitting values used are shown in Table V. 
TABLE V. Fitting Values for Equivalent Circuit.

\begin{tabular}{cccccc}
\hline $\begin{array}{c}\text { Cell } \\
\text { ID }\end{array}$ & $\begin{array}{c}\text { Temp } \\
\left({ }^{\circ} \mathbf{C}\right)\end{array}$ & R1 (Ohms) & R2 (Ohms) & R3 (Ohms) & $\mathbf{R}_{\mathbf{T}}$ (Ohms) \\
\hline Cell 1 & 700 & 616 & 12542 & 4059 & 17217 \\
& 750 & 495 & 2305.1 & 654 & 3454.1 \\
& 800 & 370 & 295.03 & 175 & 840.03 \\
Cell 2 & 700 & 236 & 25003 & 6038.6 & 31277.6 \\
& 750 & 400 & 5365 & 1925 & 7690 \\
& 800 & 345.4 & 650 & 250 & 1245.4 \\
Cell 3 & 700 & 261.23 & 18626 & 6645 & 25532.23 \\
& 750 & 315.17 & 3331 & 968.64 & 4614.81 \\
& 800 & 335.26 & 576.24 & 226.01 & 1137.51 \\
Cell 4 & 700 & 327 & 21789 & 7472.9 & 29588.9 \\
& 750 & 291.4 & 5492.2 & 1642.8 & 7426.4 \\
& 800 & 444 & 1332.5 & 413.3 & 2189.8 \\
\hline
\end{tabular}

By comparing the changing values of the overall resistance of the cells $\left(R_{T}=R_{1}+R_{2}\right.$ $+\mathrm{R}_{3}$ ), the effect of the addition of the CMF pore former to the ECD anodes can be determined. At $800^{\circ} \mathrm{C}$ the ohmic resistance will be at its lowest, therefore by examining the variation of $R_{T}$ at this temperature, where the polarisation resistance will be the dominating factor in the overall resistance of the cell, these values are shown in Figure 7.

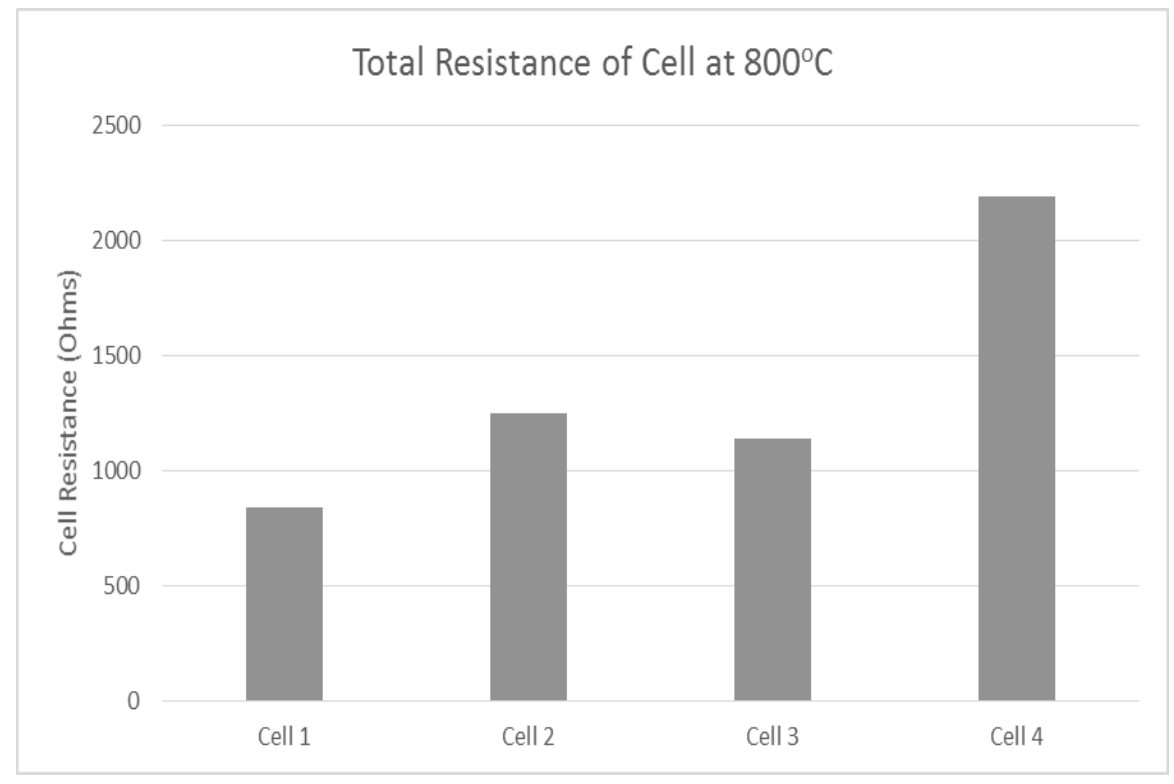

Figure 7. Total Resistance of Cell at $800^{\circ} \mathrm{C}$

Figure 7 shows that as the bath loading has increased the overall resistance of the cell has decreased. Cell 4 had the greatest resistance which had no pore former inclusion and Cell 1 had the lowest resistance with using $10 \mathrm{~g} / 1$ of CMF as a pore former. When the bath loading is compared to the overall resistance of the cell, a clear pattern can be seen, this is shown in Figure 8. 


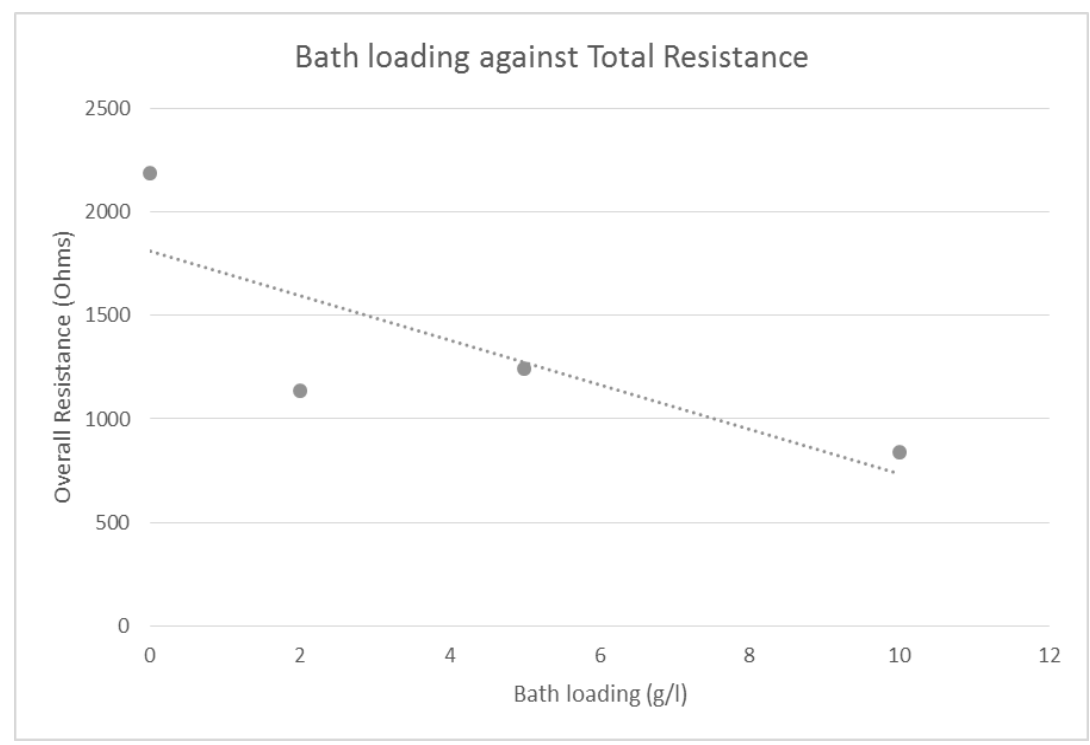

Figure 8. bath loading versus overall resistance of the Cell.

\section{Conclusion}

This study has shown the addition of the CMF into the ECD process has improved the OCV and power density capabilities of the cell. A bath loading of $10 \mathrm{~g} / \mathrm{l}$ was able to improve the $\mathrm{OCV}$ from $0.69 \mathrm{~V}$ to $1.09 \mathrm{~V}$ and improve the power density from $0.027 \mathrm{~mW}$ $\mathrm{cm}^{-2}$ to $0.108 \mathrm{~mW} \mathrm{~cm}^{-2}$ at $800^{\circ} \mathrm{C}$. This can be attributed to the reduction of the overall resistance of the cell from $2189 \Omega$ to $840 \Omega$. Since at $800^{\circ} \mathrm{C}$ the major resistance will be from the electrodes rather from the electrolyte, this reduction in resistance can attributed to the improvement of the anode microstructure, since all cells had the same cathode. Therefore, the CMF is suitable to be used within the production of ECD anodes as it is improving the microstructure allowing for an increase in TPB and gas diffusion. However, the power density was smaller than expected, yet an improvement was made. This small power density could be could be due to the CMF interfering with the platting process, producing a thin flaky anode during production. CMF is only available in solution form, since when it is dried it forms irreversible hydrogen bonding, therefore a cellulose powder would be more suitable to be used as it would not interfere with the plating process. Consequently, more research should be focused on finding a cellulose powder which has a fibrous morphology with the appropriate size to be included within the coating. This would simplify the process as a powder is much easier to add to the ECD bath and would not interfere with the plating process.

\section{References}

1. N. Mahato, A. Banerjee, A. Gupta, S. Omar, and K. Balani, "Progress in material selection for solid oxide fuel cell technology: A review," Prog. Mater. Sci., 72, 141-337 (2015).

2. S. P. S. Shaikh, A. Muchtar, and M. R. Somalu, "A review on the selection of anode materials for solid-oxide fuel cells," Renew. Sustain. Energy Rev., 51, 1-8 (2015). 
3. N. B. Baba, "Novel Processing of Solid Oxide Fuel Cell Anodes," Edinburgh Napier University, 2011.

4. A. Sarikaya, V. Petrovsky, and F. Dogan, "Effect of the anode microstructure on the enhanced performance of solid oxide fuel cells," Int. J. Hydrogen Energy, 37(15), 11370-11377 (2012).

5. W. P. Pan, Z. Lü, K. F. Chen, Y. H. Zhang, B. Wei, Z. H. Wang, and W. H. Su, "Enhanced Performance of Solid Oxide Fuel Cell by Manipulating the Orientation of Cylindrical Pores in Anode Substrate," Fuel Cells, 12(1), 41-46 (2012).

6. N. B. Baba, W. Waugh, and A. M. Davidson, "Manufacture of Electroless Nickel / YSZ Composite Coatings," World Acad. Sci. Eng. Technol., 49(1), 715-720, (2009).

7. W. P. Pan, Z. Lü, K. F. Chen, X. B. Zhu, X. Q. Huang, Y. H. Zhang, B. Wei, and W. H. Su, "Paper-Fibres Used as a Pore-Former for Anode Substrate of Solid Oxide Fuel Cell," Fuel Cells, 11(2), pp. 172-177 (2011).

8. O. Nechyporchuk, M. N. Belgacem, and J. Bras, "Production of cellulose nanofibrils: A review of recent advances," Ind. Crops Prod., 2015. 